\title{
What is the Impact of Implant-supported Mandibular Overdentures on Oral Health-Related Quality of Life? A Retrospective Study
}

\author{
Mehmet Ali Altay ${ }^{1}(\mathbb{D})$, Mehmet Mustafa Ozarslan² ${ }^{(\mathbb{D}}$, Nelli Yildirimyan ${ }^{3}$ (D), Alper Sindel ${ }^{1}$ (D) \\ ${ }^{1}$ Akdeniz University, School of Dentistry, Department of Oral and Maxillofacial Surgery, Antalya, Turkey. \\ ${ }^{2}$ Akdeniz University, School of Dentistry, Department of Prosthodontics, Antalya, Turkey. \\ ${ }^{3}$ Akdeniz University, School of Dentistry, Department of Oral and Maxillofacial Surgery, Antalya, Turkey. \\ Correspondence Author: Mehmet Mustafa Ozarslan \\ E-mail: drozarslan@hotmail.com \\ Received: 09.07.2018 Accepted: 29.08.2018
}

\begin{abstract}
Objective: Oral health-related quality of life (QoL) is significantly influenced by the type of the prostheses that is used for prosthetic rehabilitation of patients with complete edentulism. This study aims to retrospectively evaluate the outcomes of mandibular implant-supported overdentures (MODs) through patients' perceptions by analyzing the results from OHIP-14 index.

Methods: Relationships between OHIP-14 scores, and clinical and patient-based findings are investigated.

Results: Forty-seven patients were included in the study. OHIP-14 scores ranged from 0 to 35 , with a mean score of 5.81 ( \pm 6.89 ), indicating an overall "very high" quality of life. Patients with "very high" QoL had significantly lower pain scores than those with both "high" and "low" QoL ( $p=0.000$, $p=0.036$ respectively). Further analysis revealed a positive correlation between total OHIP points and pain level $(r=0.738, p=0.000)$.

Conclusion: Within the limitations of this study, it can be concluded that patients with complete edentulism of the mandible can effectively be rehabilitated with two implant-supported mandibular overdentures and be provided with a "very high" oral health-related QoL.

Keywords: quality of life, edentulous, mandible, overdenture, dental implant
\end{abstract}

\section{INTRODUCTION}

A minimum of 20 natural teeth or occluding posterior pairs of teeth are essential in order to have a satisfactory oral health (1). With increasing age tooth loss becomes inevitable, leading to a decrease in oral health-related quality of life $(2,3)$. However, even though the incidence of complete edentulism is on the decline and is reported to be $4.1 \%$ globally, total elimination of it remains unlikely in the near future (4). In our day, complete edentulism is managed by means of conventional dentures or implant-supported overdentures (5).

Prosthetic rehabilitation enhances physical, psychological and social well-being of patients. However mandibular conventional dentures stand to be a major handicap for many patients due to lacking denture retention (6). This may cause disappointing outcomes even when excellent dentures are fabricated (7). Functional limitations during eating and speaking, psychological and social disabilities, mobility, and discomfort are the mainly encountered problems with mandibular conventional complete dentures $(5,8)$. On the other hand, mandibular implant-supported overdentures (MODs) provide superior retention and stabilization, ease of use and good esthetics $(6,9)$. Masticatory efficiency is also positively affected after edentulism is treated with an implant-supported overdenture, compared to conventional complete dentures, which cause a decrease in masticatory efficiency to almost $30 \%$ to that of natural dentition $(6,10,11)$.

Previously, a 14-item questionnaire titled "Oral Health Impact Profile (OHIP-14) Index" has been developed to mainly cover the negative impacts of oral health-related QoL, contrary to several other oral health-dependent QoLquestionnaires, which capture both positive and negative impacts (9-12). OHIP-14 consists of two questions for each functional limitation, physical pain, psychological discomfort, physical, psychological and social dimensions of disability and handicaps, and higher scores are indicative of a lower quality of life (13).

Oral health-related quality of life $(\mathrm{Q} o L)$ is significantly influenced by the type of the prostheses $(8,9,14)$. Therefore, this study aims to retrospectively present our findings regarding the outcomes of MODs through patients' perceptions by analyzing the results from OHIP-14 index. Additionally, relationships between OHIP-14 scores, and clinical and patient-based findings are also investigated.

\section{METHODS}

A retrospective study was conducted at the Department of Oral and Maxillofacial Surgery, Akdeniz University, Antalya, Turkey. Seventy-four patients with mandibular complete 
edentulism who were treated with two implant-retained mandibular overdentures between January 2012 and March 2015 were invited to follow-up. Socio-demographic information (age, education, oral hygiene frequencies) was collected. Oral Health Impact Profile Index (OHIP-14) questionnaire was completed by each patient before clinical examination under the assistance of the researcher. Answers were numbered from 0 to 4 , corresponding to never, hardly ever, occasionally, fairly often and very often, respectively. Total scores were obtained by adding item scores without weighting (15). Higher scores revealed worse and lower scores indicated better oral health-related quality of life. These scores were further categorized into groups as shown in Table 1. Patients were asked to rate their pain, while using their MODs, through a Visual Analogue Scale (VAS) which ranged from 0 to 10 . A score of 0 referred to no pain and a score of 10 corresponded to the worst pain imaginable.

Table 1. Interpretation of OHIP-14 Scores

\begin{tabular}{|l|l|}
\hline Score & Quality of life \\
\hline $0-14$ & Very High \\
\hline $15-28$ & High \\
\hline $28-42$ & Low \\
\hline $42-56$ & Very Low \\
\hline OHIP: Oral Health Impact Profile & \\
\hline
\end{tabular}

All dentures were removed for clinical examination. Soft tissues of the oral cavity were inspected for any signs of inflammation, swelling, bleeding or pus drainage. Periimplant tissues were also visually examined first; then, pocket probing depth and bleeding on probing from six sites of each implant, as well as implant mobility were evaluated. To achieve optimum probe force reproducibility and accuracy, all examinations of peri-implant tissues were performed under light force $(0.2-0.25 \mathrm{~N}-$ about 25 grams of pressure) using the same type of stainless steel periodontal probe (Williams Probe, Hu-Friedy Manufacturing Co., LLC, Chicago, IL, United States) graded at 1-2-3-5-7-8-9 and $10 \mathrm{~mm}$. New orthopantomographic images were obtained only for patients whose radiographs were not taken within one year. Clinical and radiographic examination results were incorporated to detect peri-implant pathologies, diagnosed according to the criteria stated on the Consensus Report of the Seventh European Workshop on Periodontology(16).

All patients were informed about details of the study. The study was approved by the Ethical Committee of Akdeniz University, Antalya, Turkey (No: 2018-447). All procedures on human subjects were conducted in accordance with the Declaration of Helsinki, and with the adequate understanding and written consent of the patients.

\subsection{Statistical analysis}

All data were analyzed using the Statistical Package for Social Sciences version 22.0 (IBM SPSS Statistics 22, SPSS Inc., Chicago, IL, USA). Appropriate analyses were employed according to relevant data characteristics. Spearman correlation test was used to determine a correlation between OHIP-14 scores and VAS results. P values of $<.05$ were used to assess the significance for all statistical analyses. All values for each parameter were tested for normality using the Shapiro-Wilk test, which rejected the hypothesis of normality for all parameters $(p=0.000)$

\section{RESULTS}

Forty-seven patients out of 74, whose details on sociodemographics are summarized in Table 2 presented to their follow-up appointments. Twenty-eight female and 19 male patients within their fifth, sixth, seventh and eight decades of life were included.

Table 2. Socio-demographic characteristics

\begin{tabular}{|l|l|}
\hline Characteristics & N \\
\hline Age & 11 \\
\hline $\mathbf{5 0}-59$ & 18 \\
\hline $\mathbf{6 0 - 6 9}$ & 15 \\
\hline $\mathbf{7 0 - 7 9}$ & 3 \\
\hline $\mathbf{8 0 - 8 9}$ & \\
\hline Gender & 28 \\
\hline Female & 19 \\
\hline Male & \\
\hline Educational Level & 6 \\
\hline None & 20 \\
\hline Elementary & 4 \\
\hline Middle School & 7 \\
\hline High School & 10 \\
\hline University & \\
\hline Oral Hygiene Habits - Frequency & 6 \\
\hline Never & 18 \\
\hline Once a day & 18 \\
\hline Twice a day & 5 \\
\hline Three times a day & \\
\hline
\end{tabular}

Six patients were uneducated, 10 patients were college graduates and the remaining had at least elementary level education. Forty-one patients reported to clean their dentures and brush their implants at least once a day; whereas, 6 patients had no oral hygiene habits. A majority of patients $(n=27)$ had conventional dentures on the opposite arch, 17 had partial prostheses, 2 were using implantsupported maxillary overdentures and the remaining patient had fixed dentures.

OHIP-14 scores ranged from 0 to 35 , with a mean score of 5.81 ( \pm 6.89$)$, indicating an overall "very high" quality of life. Forty-one patients each scored less than 14 points corresponding to a "very high" QoL. Five patients received a score equivalent to a QoL of "high" and the remaining patient achieved a score indicating a "low" QoL.

Mean peri-implant probing depths on the right and left implants were $2.04 \mathrm{~mm}$ (SD: 1.13 ) and $2.14 \mathrm{~mm}$ (SD: 1.45) respectively. The difference between the probing depths of left and right peri-implant tissues were statistically not significant ( $p=0.866$, Wilcoxon test). Similarly, no differences were found between probing depths of patients with "very high", "high" or "low" QoL (Table 3; p>0.05, Kruskal-Wallis test). 
Table 3. Test Statistics

\begin{tabular}{|c|c|c|c|}
\hline Null Hypothesis & Test & Sig. & Decision \\
\hline $\begin{array}{l}\text { The distribution of "Right } \\
\text { Periimplant Probing Depth" } \\
\text { is the same across the } \\
\text { categories of "Quality of } \\
\text { Life"*. }\end{array}$ & Kruskal-Wallis & 0.568 & $\begin{array}{l}\text { Retain the null } \\
\text { hypothesis }\end{array}$ \\
\hline $\begin{array}{l}\text { The distribution of "Left } \\
\text { Periimplant Probing Depth" } \\
\text { is the same across the } \\
\text { categories of "Quality of } \\
\text { Life"*. }\end{array}$ & Kruskal-Wallis & 0.371 & $\begin{array}{l}\text { Retain the null } \\
\text { hypothesis }\end{array}$ \\
\hline
\end{tabular}

After their examinations, 16 patients were diagnosed with stomatitis while others had no prosthesis-related pathologies. Peri-implant examinations revealed 8 patients with periimplant mucositis and 4 patients with peri-implantitis (16). Figure $1 \mathrm{~A}$ and $1 \mathrm{~B}$ analyze OHIP score interpretations for patients with prosthesis and implant related pathologies, respectively. Overall, no statistically significant associations were found between OHIP-14 scores, and age, gender, education level, oral hygiene routines, type of maxillary prosthesis or pathologies related to implants or dentures (Table 4; $p>0.05$, Kruskal-Wallis test).

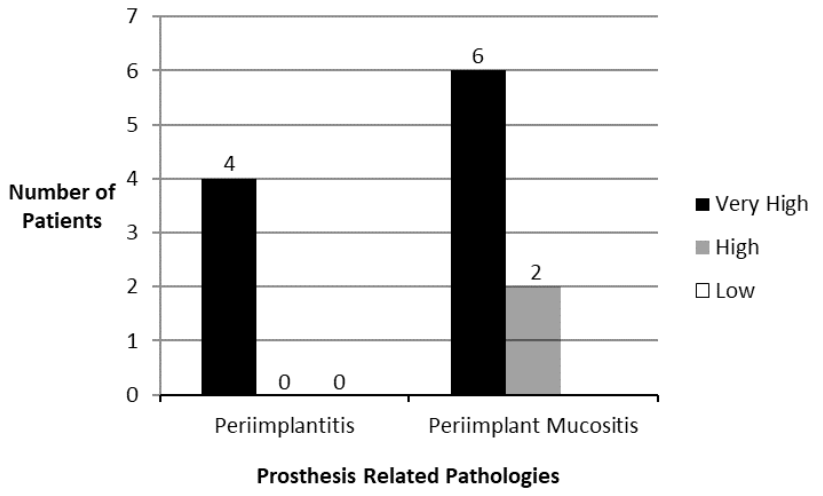

Figure 1A: Bar chart showing OHIP score interpretations for patients with prosthesis related pathologies.

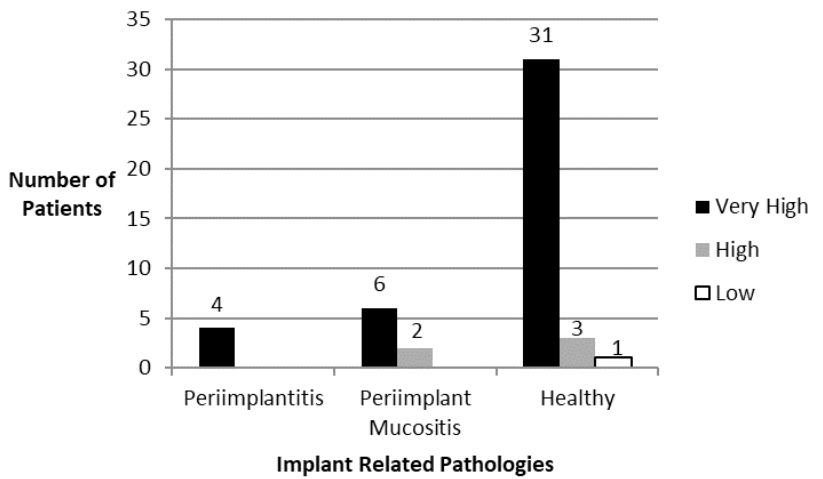

Figure 1B: Bar chart showing OHIP score interpretations for patients with implant related pathologies.
Table 4. Test Statistics

\begin{tabular}{|c|c|c|c|}
\hline Null Hypothesis & Test & Sig. & Decision \\
\hline $\begin{array}{l}\text { The distribution of "Age" is the } \\
\text { same across the categories of } \\
\text { "Quality of Life"*. }\end{array}$ & $\begin{array}{l}\text { Kruskal- } \\
\text { Wallis }\end{array}$ & 0.536 & $\begin{array}{l}\text { Retain the null } \\
\text { hypothesis }\end{array}$ \\
\hline $\begin{array}{l}\text { The distribution of "Gender" is } \\
\text { the same across the categories of } \\
\text { "Quality of Life"*. }\end{array}$ & $\begin{array}{l}\text { Kruskal- } \\
\text { Wallis }\end{array}$ & 0.478 & $\begin{array}{l}\text { Retain the null } \\
\text { hypothesis }\end{array}$ \\
\hline $\begin{array}{l}\text { The distribution of "Education } \\
\text { Level" is the same across the } \\
\text { categories of "Quality of Life"*. }\end{array}$ & $\begin{array}{l}\text { Kruskal- } \\
\text { Wallis }\end{array}$ & 0.205 & $\begin{array}{l}\text { Retain the null } \\
\text { hypothesis }\end{array}$ \\
\hline $\begin{array}{l}\text { The distribution of "Oral Hygiene } \\
\text { Routines" is the same across the } \\
\text { categories of "Quality of Life"*. }\end{array}$ & $\begin{array}{l}\text { Kruskal- } \\
\text { Wallis }\end{array}$ & 0.155 & $\begin{array}{l}\text { Retain the null } \\
\text { hypothesis }\end{array}$ \\
\hline $\begin{array}{l}\text { The distribution of "Type of } \\
\text { Maxillary Prosthesis" is the same } \\
\text { across the categories of "Quality of } \\
\text { Life"*. }\end{array}$ & $\begin{array}{l}\text { Kruskal- } \\
\text { Wallis }\end{array}$ & 0.241 & $\begin{array}{l}\text { Retain the null } \\
\text { hypothesis }\end{array}$ \\
\hline $\begin{array}{l}\text { The distribution of "Implant-Related } \\
\text { Pathologies" is the same across the } \\
\text { categories of "Quality of Life"*. }\end{array}$ & $\begin{array}{l}\text { Kruskal- } \\
\text { Wallis }\end{array}$ & 0.723 & $\begin{array}{l}\text { Retain the null } \\
\text { hypothesis }\end{array}$ \\
\hline $\begin{array}{l}\text { The distribution of "Denture- } \\
\text { Related Pathologies" is the same } \\
\text { across the categories of "Quality of } \\
\text { Life"*. }\end{array}$ & $\begin{array}{l}\text { Kruskal- } \\
\text { Wallis }\end{array}$ & 0.355 & $\begin{array}{l}\text { Retain the null } \\
\text { hypothesis }\end{array}$ \\
\hline
\end{tabular}

Pain was the only parameter that showed a significant difference among different levels of $\mathrm{QoL}$ ( $p=0.000$, Kruskal-Wallis test). Post-hoc analyses revealed that patients with "very high" QoL had significantly lower pain scores than those with both "high" and "low" QoL ( $p=0.000, p=0.036$ respectively). Details of these findings are shown in Table 5. Further analysis revealed a strong positive correlation between total OHIP points and pain level (Table 6; $r=0.738, p=0.000$; Spearman correlation test).

Table 5a. Test Statistics

Null Hypothesis Test Sig. Decision

\begin{tabular}{|l|l|l|l|l}
\hline The distribution of "Pain" is & & Reject the null \\
\hline
\end{tabular}

the same across the categories Kruskal-Wallis 0.000 Rypothesis of "Quality of Life"*.

*Categories of "Quality of Life"; "very high", "high" or "low"

Sig.; Significance

Table 5b. Post-hoc Analyses

\begin{tabular}{|l|l|}
\hline "Quality of Life" Comparisons & Sig. \\
\hline Very High - High & 0.000 \\
\hline Very High - Low & 0.036 \\
\hline High - Low & 0.693 \\
\hline
\end{tabular}

Table 6. Spearman's Test of Correlation

\begin{tabular}{|l|l|l|l|}
\hline OHIP Score & Correlation Coefficient & 1 & $.738^{* *}$ \\
\hline & Sig. (2-tailed) & & .000 \\
\hline & $\mathrm{N}$ & 47 & 47 \\
\hline Pain & Correlation Coefficient & $.738^{* *}$ & 1 \\
\hline & Sig. (2-tailed) & .000 & \\
\hline & N & 47 & 47 \\
\hline
\end{tabular}

** Correlation is significant at the 0.01 level (2-tailed)

OHIP: Oral Health Impact Profile 


\section{DISCUSSION}

According to the World Health Organization, oral health is defined as "being free of chronic oro-facial pain, oral and pharyngeal cancer, oral tissue lesions, birth defects such as cleft lip and palate and other diseases and disorders that affect the oral, dental and craniofacial tissues" (17). Oral health is vital for general health and well-being as well as good quality of life, and should not just be associated with good teeth $(17,18)$. Poor oral health compromises chewing and eating abilities, consequently affecting nutritional intake negatively $(6,10,17)$. It is not surprising to expect edentulism to have adverse effects on the quality of life, since not only chewing and swallowing but also speaking and smiling are among essential functions of the orofacial complex $(2,8,17)$.

Conventional or implant-supported overdentures may be fabricated to rehabilitate an edentulous patient (5). Conventional mandibular dentures are dissatisfactory usually because of denture instability and discomfort (19). Unstable dentures are the reason for pain and pathological conditions such as traumatic ulcers and irritation-induced hyperplasia (20). The main reason behind the instability of mandibular conventional dentures is due to the alveolar bone resorption following tooth extraction. Patients experience a more dramatic reduction in bone volume in the mandible than in the maxillary bone. Thus, not only denture adaptation and acceptance becomes problematic by patients, but also the construction becomes challenging for the dentists (19). Moreover, patients with conventional dentures experience more residual ridge resorption than MOD users, which may even worsen the adaptation process as the patients continue to use the conventional dentures (21). Also in the long term, denture instability is known to reduce masticatory function, impair phonetic abilities and negatively affect social and psychological life of the patient $(8,11)$. Altered perception in taste and burning mouth syndrome have also been reported (19).

On the other hand, implants, particularly in the anterior mandible, are shown to slow the resorption process and reduce mandibular bone loss $(22,23)$. Implant-supported mandibular overdentures not only provide better stability, but also increase comfort and ease denture acceptance $(24,25)$. However, main disadvantages of MODs are their high cost and relatively lengthy treatment duration (19).

In 2002, the McGill consensus on overdentures concluded that conventional complete dentures were no longer the most appropriate treatment for the restoration of edentulous mandible due to the conclusive evidence in favor of two-implant supported MODs and against conventional prostheses (26). The same statement was articulated by the British Society for the Study of Prosthetic Dentistry in 2009 who defined MODs as the "first choice of standard of case for edentulous patients" and published their declaration under the title "the York Consensus Statement" (5).

A meta-analysis in 2012, also proved that patients with MODs had greater oral-health related QoL and were more satisfied with their dentures, which was compatible with the results of the current study and in agreement with the McGill and York consensuses $(5,26,27)$.

Pain was the only parameter in this study to be significantly associated with OHIP-14 scores. Knipfer et al. suggested that freedom of pain had a noticeable role in an improved oral-health related quality of life (28). The most recent systematic review comparing conventional dentures and implant-retained overdentures similarly stated that MODs were associated with less physical pain, and reported the superiority of MODs with regards to patient satisfaction and quality of life (29).

In 1990, a prevalence of $75 \%$ was reported among the elderly population of Turkey for edentulism (2). In 2004, this rate was decreased to $48 \%$ but it is still considered high compared to other countries $(30,31)$. Despite growing technology and innovations, complete edentulism does not seem to be eradicated in the near future (4). Today, MODs seem to have taken over conventional complete dentures, since more and more studies reporting favorable outcomes of implant-retained overdentures are being published $(29,32,33)$. According to the results of the present study, and the literature, patients with implant-supported MODs are satisfied with the outcome of MOD-treatment.

Main limitations of this study are its retrospective nature, the unavailability of pre-implant OHIP-14 scores or the lack of a control group, which prohibited a true comparison between patients with MODs and conventional mandibular dentures.

\section{CONCLUSION}

Within the limitations of this study, it may be concluded that patients were satisfied with their MODs and presented a "very high" QoL, which was in accordance with the literature. Moreover, higher pain scores were associated with lower QoL.

Conflict of Interest: Dr. Altay has provided consultancy for Checkpoint Surgical LLC. İ 2014. Other authors declare that they have no relevant conflicts of interest.

\section{REFERENCES}

[1] Sheiham A, Steele JG, Marcenes W, Lowe C, Finch S, Bates CJ, Prentice A, Walls AWG. The Relationship among Dental Status, Nutrient Intake, and Nutritional Status in Older People. J Dent Res. 2001;80(2):408-413.

[2] Dogan BG, Gokalp S. Tooth loss and edentulism in the Turkish elderly. Arch Gerontol Geriatr. Netherlands: A 2012 Elsevier Ireland Ltd; 2012:e162-e166.

[3] Astrom AN, Haugejorden O, Skaret E, Trovik TA, Klock KS. Oral Impacts on Daily Performance in Norwegian adults: the influence of age, number of missing teeth, and sociodemographic factors. Eur J Oral Sci. Apr 2006;114(2):115-121.

[4] Felton DA. Complete edentulism and comorbid diseases: an update. J Prosthodont. 2015:5-20. 
[5] Thomason JM, Feine J, Exley C, Moynihan P, Muller F, Naert I, Ellis JS, Barclay C, Butterworth C, Scott B, Lynch C, Stewardson D, Smith P, Welfare R, Hyde P, McAndrew R, Fenlon M, Barclay $S$ and Barker D. Mandibular two implantsupported overdentures as the first choice standard of care for edentulous patients - the York Consensus Statement. Br Dent J. 22 2009;207(4):185-186.

[6] Sun X, Zhai J-J, Liao J, Teng M-H, Tian A, Liang X. Masticatory efficiency and oral health-related quality of life with implant-retained mandibular overdentures. Saudi Med J. 2014;35(10):1195.

[7] Cakir O, Kazancioglu HO, Celik G, Deger S, Ak G. Evaluation of the efficacy of mandibular conventional and implant prostheses in a group of Turkish patients: a quality of life study. J Prosthodont. Jul 2014;23(5):390-396.

[8] Sivaramakrishnan G, Sridharan K. Comparison of implant supported mandibular overdentures and conventional dentures on quality of life: a systematic review and metaanalysis of randomized controlled studies. Aust Dent J. 2016;61(4):482-488.

[9] Kuoppala R, Näpänkangas R, Raustia A. Quality of Life of Patients Treated With Implant-Supported Mandibular Overdentures Evaluated With the Oral Health Impact Profile (OHIP-14): A Survey of 58 Patients. J Oral Maxillofac Res. 2013;4(2):e4.

[10] 1Farias NA, Moreira dFPB, Lopes XR, Rocha GA, Medeiros RJA, Wilson MJ and Carreiro Ada F. The influence of mandibular implant-retained overdentures in masticatory efficiency. Gerodontol. 2012;29(2):e650-e655.

[11] 1Fueki K, Kimoto K, Ogawa T, Garrett NR. Effect of implantsupported or retained dentures on masticatory performance: a systematic review. J Prosthet Dent. 2007;98(6):470-477.

[12] 1Slade GD. Derivation and validation of a short-form oral health impact profile. Community Dent Oral Epidemiol. 1997;25(4):284-290.

[13] 1Başol ME, Karaağaçlıoğlu L, Yılmaz B. Türkçe Ağız Sağlığı Etki Ölçeğinin Geliştirilmesi-OHIP-14-TR. Turkiye Klinikleri. Dishekimligi Bilimleri Dergisi. 2014;20(2)(Turkish).

[14] 1Boven GC, Raghoebar GM, Vissink A, Meijer HJ. Improving masticatory performance, bite force, nutritional state and patient's satisfaction with implant overdentures: a systematic review of the literature. J Oral Rehabil. 2015;42(3):220-233.

[15] Allen PF, Locker D. Do item weights matter? An assessment using the oral health impact profile. Community Dent Health. 1997;14(3):133-138.

[16] Lang NP, Berglundh T. Periimplant diseases: where are we now?-Consensus of the Seventh European Workshop on Periodontology. J Clin Periodontol. 2011;38 Suppl 11:178181.

[17] Petersen PE. The World Oral Health Report 2003: continuous improvement of oral health in the 21st century-the approach of the WHO Global Oral Health Programme. Community Dent Oral Epidemiol. 2003;31:3-23.

[18] Glick M, Monteiro da Silva O, Seeberger GK, Xu T, Pucca G, Williams DM, Kess S, Eiselé JL, Séverin T. FDI Vision 2020: shaping the future of oral health. Int. Dental J.. 2012;62(6):278291.

[19] Cooper LF. The current and future treatment of edentulism. J Prosthodont. 2009;18(2):116-122.

[20] MacEntee MI, Nolan A, Thomason JM. Oral mucosal and osseous disorders in frail elders. Gerodontol. 2004;21(2):78-84.
[21] Kordatzis K, Wright PS, Meijer HJ. Posterior mandibular residual ridge resorption in patients with conventional dentures and implant overdentures. Int J Oral Maxillofac Imp. 2003;18(3):447-452

[22] Von Wowern N, Gotfredsen K. Implant-supported overdentures, a prevention of bone loss in edentulous mandibles? Clin Oral Imp Res. 2001;12(1):19-25.

[23] Burns DR. Mandibular implant overdenture treatment: consensus and controversy. J Prosthodont. 2000;9(1):37-46.

[24] Heydecke G, Klemetti E, Awad MA, Lund JP, Feine JS. Relationship between prosthodontic evaluation and patient ratings of mandibular conventional and implant prostheses. Int J Prosthodont. 2003;16(3):307-312.

[25] Awad MA, Lund JP, Dufresne E, Feine JS. Comparing the efficacy of mandibular implant-retained overdentures and conventional dentures among middle-aged edentulous patients: satisfaction and functional assessment. Int J Prosthodont. 2003;16(2):117-122.

[26] Feine JS, Carlsson GE, Awad MA, Chehade A, Duncan WJ, Gizani S, Head T, Heydecke G, Lund JP, MacEntee M, MericskeStern R, Mojon P, Morais JA, Naert I, Payne AG, Penrod J, Stoker GT, Tawse-Smith A, Taylor TD, Thomason JM, Thomson WM, and Wismeijer D. The McGill consensus statement on overdentures. Mandibular two-implant overdentures as first choice standard of care for edentulous patients. Gerodontol. 2002;19(1):3-4.

[27] Thomason JM. The use of mandibular implant-retained overdentures improve patient satisfaction and quality of life. J Evid Based Dent Pract. 2012;12(3 Suppl):182-184.

[28] Knipfer C, Riemann M, Bocklet T, Noeth E, Schuster M, Sokol B, Eitner S, Nkenke E, and Stelzle F. Speech intelligibility enhancement after maxillary denture treatment and its impact on quality of life. Int J Prosthodont. 2014;27(1):6169.

[29] Kutkut A, Bertoli E, Frazer R, Pinto-Sinai G, Fuentealba Hidalgo R, Studts J. A systematic review of studies comparing conventional complete denture and implant retained overdenture. J Prosthodont Res. Jan 2018;62(1):1-9.

[30] Kailembo A, Preet R, Stewart Williams J. Common risk factors and edentulism in adults, aged 50 years and over, in China, Ghana, India and South Africa: results from the WHO Study on global AGEing and adult health (SAGE). BMC Oral Health. 2016;17(1):29:1-16.

[31] Peltzer K, Hewlett $S$, Yawson AE, Moynihan P, Preet R, Wu F, Guo G, Arokiasamy P, Snodgrass JJ, Chatterji S, Engelstad $\mathrm{ME}$, and Kowal P. Prevalence of loss of all teeth (edentulism) and associated factors in older adults in China, Ghana, India, Mexico, Russia and South Africa. Int J Environ Res Public Health. 30 2014;11(11):11308-11324.

[32] Zhang L, Lyu C, Shang Z, Niu A, Liang X. Quality of Life of Implant-Supported Overdenture and Conventional Complete Denture in Restoring the Edentulous Mandible: A Systematic Review. Implant Dent. 2017;26(6):945-950.

[33] Kroll P, Hou L, Radaideh H, Sharifi N, Han PP, Mulligan R and Enciso R. Oral health-related outcomes in edentulous patients treated with mandibular implant-retained dentures versus complete dentures: Systematic review with meta-analyses. J Oral Implantol. 2018:313-324. 
How to cite this article: Altay M. A., Ozarslan M. M., Yildirimyan N., Sindel A. What is the Impact of Implant-supported Mandibular Overdentures on Oral Health-Related Quality of Life? A Retrospective Study. Clin Exp Health Sci 2019; 9: 101-106. DOI: 10.33808/ clinexphealthsci.475303 